\title{
MENINGKATKAN KEMAMPUAN GURU DALAM MENYUSUN RKH DALAM PEMBELAJARAN BCCT
}

\author{
Airin Setyarini \\ TK Negeri Pratama Malinau \\ Email: airin183@gmail.com
}

\begin{abstract}
Abstrak
Sebuah kegiatan pembelajaran dalam PAUD tanpa adanya Rencana Kegiatan Harian (RKH) tentu akan menghambat kelancaran proses pembelajaran dan tujuan dari kegiatan pembelajaran juga tidak akan tercapai. Kehadiran kepala sekolah baru memberi warna yang berbeda dengan mengubah pembelajaran yang tadinya klasikal menjadi bentuk sentra. Dengan bimbingan dan pelatihan para guru di TK N Pratama Malinau mulai dapat membuat RKH dan menerapkannya dalam pembelajaran.
\end{abstract}

Kata Kunci: pembelajaran, sentra, Taman Kanak-kanak

\section{Abstract}

A learning activity in Pendidikan Anak Usia Dini (early childhood education) without Rencana Kegiatan Harian (daily activity plan) will surely hamper the learning process and so the learning objective will not be successful. The presence of new principal brings different atmosphere by changing the classical learning into central learning. With some guidance and trainings, teachers in TK N Pratama Malinau can be able to make RKH and implement it in the learning process.

Keywords: learning, central, kindergarten

\section{PENDAHULUAN}

Pendidikan anak usia dini merupakan pendidikan yang terpenting untuk meletakkan dasar-dasar perkembangan. Di dalam UU No 20 tahun 2003

tentang sistem pendidikan nasional menyiratkan bahwa anak usia dini ialah anak yang berada pada rentang masa usia lahir sampai usia enam tahun. Masa usia dini merupakan masa emas (golden age) di mana kecerdasan anak dapat berkembang dengan pesat. Anak usia dini merupakan usia emas (the golden age) yang sangat potensial untuk melatih dan mengembangkan berbagai potensi multi kecerdasan yang dimiliki anak (Harun, dkk, 2009:64).

Kelancaran sebuah proses pembelajaran tak luput dari perencanaan perangkat pembelajaran. Seorang guru harus mampu menyusun perangkat pembelajaran yang akan digunakan dalam kegiatan pembelajaran. Bagaimana jadinya kalau proses pembelajaran berlangsung tanpa adanya perencanaan sebelumnya. Hal ini tentunya akan menghambat kelancaran kegiatan pembelajaran dan tujuan dari proses pembejaran juga tidak akan tercapai.

Dalam pendidikan anak usia dini perangkat pembelajaran dikenal dengan istilah Rencana Kegiatan Harian atau RKH (sekarang RPPH). Guru-guru di TK Negeri Pratama Malinau belum paham mengenai bagaimana membuat $\mathrm{RKH}$, terlebih lagi RKH model pembelajaran BCCT dengan sentra-sentra yang baru saja diterapkan. Oleh karena itu dibutuhkan pelatihan agar para guru mampu menyusun perangkat pembelajaran demi kelancaran proses pembelajaran.

\section{Kegiatan Pembelajaran di TK Negeri Pratama Malinau}

TK Negeri Pratama Malinau terletak di Jalan Tanjung Belimbing 120 A RT VIII, Malinau Hulu, Malinau Kota, Malinau. Akses untuk menuju ke sekolah ini sangatlah mudah karena jalannya sudah 
sangat bagus dan dilewati oleh angkutan umum (taksi). TK Negeri Pratama Malinau mendapat satu orang guru SM3T untuk mengabdi selama satu tahun.

Dalam pengabdian saya di TK $\mathrm{N}$ Pratama Malinau, tenaga dan pikiran saya lebih dibutuhkan dalam kelengkapan administrasi sekolah. Jumlah guru yang ada sudah cukup memadai dengan pengalaman mengajar bertahun-tahun. Namun, tak satu pun guru di sana yang lulusan S1 PAUD, kebanyakan dari mereka hanya lulusan SMA bahkan ada yang SMP dan ada beberapa yang sarjana tetapi bukan PAUD.

Selama bertahun-tahun kegiatan pembelajaran berlangsung tanpa membuat RKH terlebih dahulu. Kurang paham dan rasa malas menurut saya menjadi alasannya. Bukan tidak pernah membuat sama sekali, ada juga guru yang pernah membuat RKH tetapi terhenti. Karakter guru yang keras dan tidak ada sosok yang disegani terlebih dengan adanya kekosongan pemimpin (kepala sekolah) yang cukup lama membuat saya juga mengalami kesulitan untuk sedikit saja mengubah kebiasaan buruk itu. Dengan berbekal LKA dalam bentuk majalah yang sangat banyak itulah yang digunakan untuk kegiatan pembelajaran sehari-hari dari senin hingga kamis, untuk hari jumatsabtu diisi kegiatan olahraga dan keagamaan.

Ada tiga kelompok di TK $\mathrm{N}$ Pratama, satu kelas kelompok A dan dua kelas kelompok B. Dalam satu kelas ada sekitar 30-40 anak dengan 4 hingga 5 guru. Pembelajaran dilakukan secara klasikal sebelum diterapkan pembelajaran BCCT pada tahun ajaran baru 2015-2016.

Perubahan ini terjadi dengan masuknya kepala sekolah baru yang tegas dan memiliki bekal ilmu tentang PAUD walaupun bukan lulusan S1PAUD. Bersama dengan kepala sekolah saya membuat gagasan untuk melatih guru-guru dalam pembuatan Rencana Kegiatan Harian (RKH). Pelatihan dilakukan diselasela libur semester II, sedangkan pelatihan secara global bersama guru-guru PAUD se-kabupaten Malinau dilakukan sehari sebelum bulan puasa.
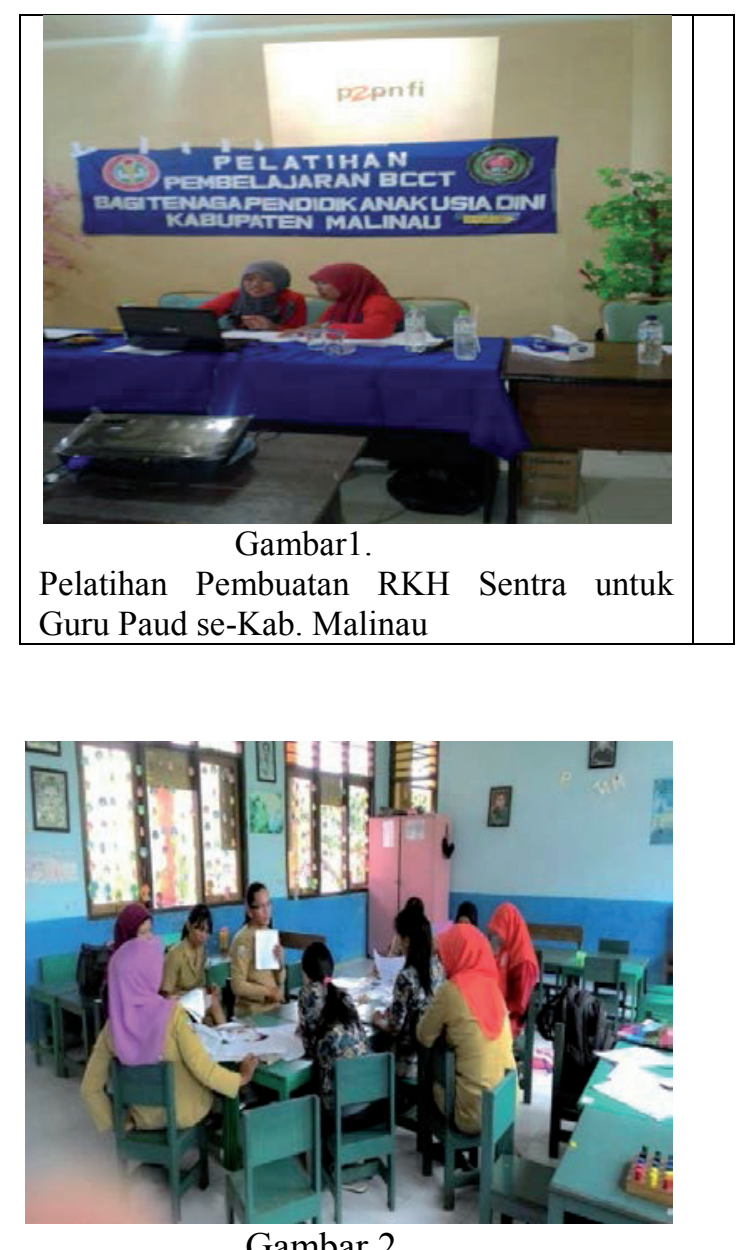

Airin dan Kepala Sekolah memberi pelatihan pada guru TK N Pratama

\section{Rencana Kegiatan Harian}

Rencana Kegiatan Harian (RKH) merupakan penjabaran dari Rancangan Kegiatan Mingguan (RKM) yang memuat kegiatan-kegiatan pembelajaran dalam satu hari. RKM sendiri merupakan penjabaran dari Program Semester (Promes) Komponen RKH, antara lain: tema/sub tema /sub-sub tema, alokasi waktu, hari/tanggal, kegiatan pembukaan, kegiatan inti, dan kegiatan penutup (Dirjen Manajemen Dikdas dan Menengah, Kemdiknas RI: 2010).

\section{Pembelajaran BCCT}

Model Beyond Center and Circle ( BCCT ) adalah suatu model atau 
pendekatan dalam penyelenggaraan pendidikan anak usia dan merupakan perpaduan antara teori dan pengalaman prakti. ( Yuliani 2009: 216). Eka Mandasari, 2009 dalam http://ejournal.unesa.ac.id/article/4980/14/ article.pdf, BCCT ( Beyond Centers and Circle Times $=$

Sistem sentra dan saat lingkaran) adalah pendekatan penyelenggaraan PAUD yang berfokus pada anak yang dalam proses pembelajarannya berpusat di sentra main dan saat dalam lingkaran. Pijakan adalah dukungan yang berubahubah yang disesuaikan dengan perkembangan yang dicapai anak yang diberikan sebagai pijakan untuk mencapai perkembangan yang lebih tinggi. Empat pijakan tersebut adalah:

1. PijakanLingkungan

- Menatalingkunganbelajar

- Menyiapkankegiatandalamsentra

- Menyiapkanalat main yang akandigunakan

2. Pijakansebelum main

- Do'a, salam, \&menyapaanaksatupersatu

- Apersepsimateri

- Membuataturan main dalamsentra

3. Pijakanselama main

- Memberiwaktu main (45' - 1 jam)

- Membimbinganakmenyelesaikant ugasnya

- Memperluasbahasadangagasande nganpertanyaanterbuka

- Mengamati\&mendokumentasikan kemajuananak

4. Pijakan setelah main

- Bersamaanakmembereskanalat main

- Recalling,

- Menghubungkandengankonsep yang akandipelajariselanjutnya

Model BCCT ini menggunakan 3 jenis main, yaitu:
1. Main sensorimotor, anak main dengan benda untuk membangun persepsi

2. Main Peran, anak bermain dengan benda untuk mewujudkan untuk membantu menghadirakan konsep yang sudah dimilikinya

3. Main Pembangunan, anak bermain dengan benda untuk mewujudkan ide/ gagasan yang dibangun dalam pikirannya menjadi sesuatu bentuk nyata.

(Assolihin, 2013 dalam

http://paudanakbermainbelajar.blogsp ot.co.id/2013/05/pengertian-konsepdan-teori-bcct.html).

\section{Macam Sentra di model BCCT:}

1. Sentra Bahan Alam.

Tempat bermain sambil belajar untuk mengembangkan pengalaman sensori motor dalam rangka menguatkan tiga jari untuk persiapan menulis, sekaligus pengenalan sains untuk anak. Efek yang diharapkan adalah Anak dapat terstimulasi aspek motorik halus secara optimal, dan mengenal sains sejak dini.

2. Sentra Main Peran Mikro atau Makro Tempat bermain sambil belajar, dimana anak dapat mengembangkan daya imajinasi dan mengekspresikan perasaan saat ini, kemarin, dan yang akan datang. Penekanan sentra ini terletak pada alur cerita sehingga anak terbiasa untuk berfikir secara istimatis. Efek yang diharapkan adalah anak dapat bersosialisasi dan berinteraksi dengan teman dan lingkungan sekitar dan mengembangkan kemampuan berbahasa secara optimal.

3. Sentra Balok

Tempat bermain sambil belajar untuk mempresentasikan ide ke dalam bentuk nyata (bangunan). Di sentra ini anak dapat memainkan balok dengan perbandingan 1 anak \pm 100 balok plus assesoris. Penekanan sentra ini pada start and finish, di mana anak mengambil balok sesuai kebutuhan dan mengembalikan dengan 
mengklasifikasi berdasarkan bentuk balok. Efek yang diharapkan adalah anak dapat berfikir tipologi, mengenal ruang dan bentuk sehingga dapat mengembangkan kecerdasan visual spasial secara optimal.

4. Sentra Persiapan

Tempat bermain sambil belajar untuk mengembangkan pengalaman keaksaraan. Di sentra ini anak difasilitasi dengan permainan yang dapat mendukung pengalaman baca, tulis, hitung dengan cara yang menyenangkan dan anak dapat memilih kegiatan yang diminati. Efek yang diharapkan adalah Anak dapat berpikir teratur, senang membaca, menulis dan menghitung.

5. Sentra Iman \& Taqwa (Religion Center).

Tempat bermain sambil belajar untuk mengembangkan kecerdasan jamak dimana kegiatan main lebih menitik beratkan pada kegiatan keagamaan. Di sentra ini anak difasilitasi dengan kegiatan bermain yang memfokuskan pada pembiasaan beribadah dan mengenal Simbol dan huruf keagamaan misalnya untuk centra Agama Islam mengenal huruf hijaiyyah dengan cara bermain sambil belajar. Efek yang diharapkan adalah tertanamnya akhlakul karimah. Ikhlas, sabar, dan senang menjalankan perintah agama.

6. Sentra Seni dan Kreativitas

Sentra ini menitik beratkan pada kemampuan anak dalam berkreasi. Kegiatan di sentra ini dilaksanakan dalam bentuk proyek, dimana anak diajak untuk menciptakan kreasi tertentu yang akan menghasilkan sebuah karya. Efek yang diharapkan adalah anak dapat berfikir secara kreatif.

\section{RKH Sentra}

Dalam penyusunan RKH Sentra berdasarkan pijakan-pijakan dan penjabaran dari RKM.

\section{RENCANA PELAKSANAAN PEMBELAJARAN MINGGUAN (RPPM) KELOMPOK BERMAIN}

Semester/Bulan/ Minggu : 2/ / 14

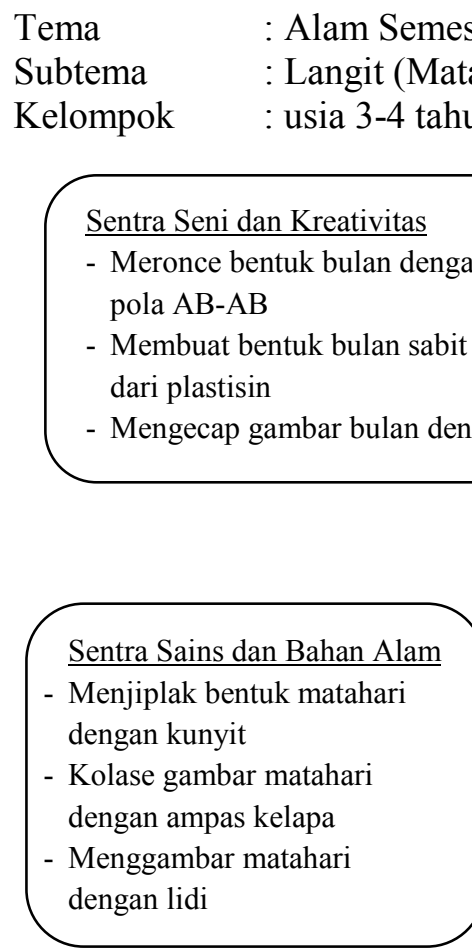

ari, bulan, bintang)

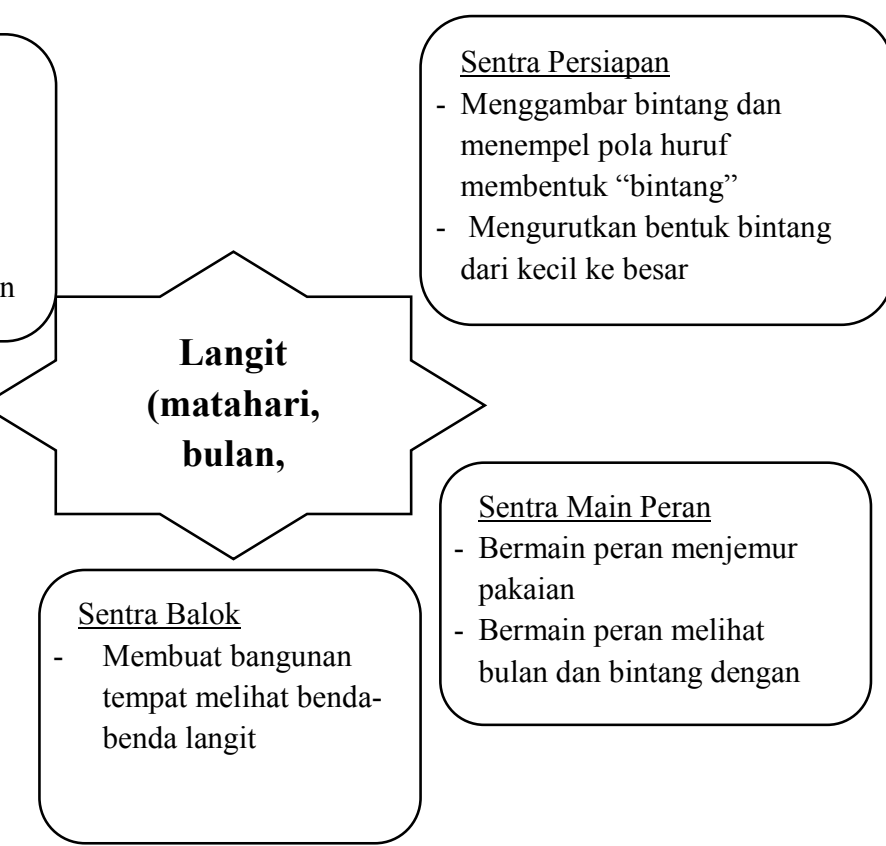


Jurnal Pendidikan Anak, Volume IV, Edisi 2, Desember 2015
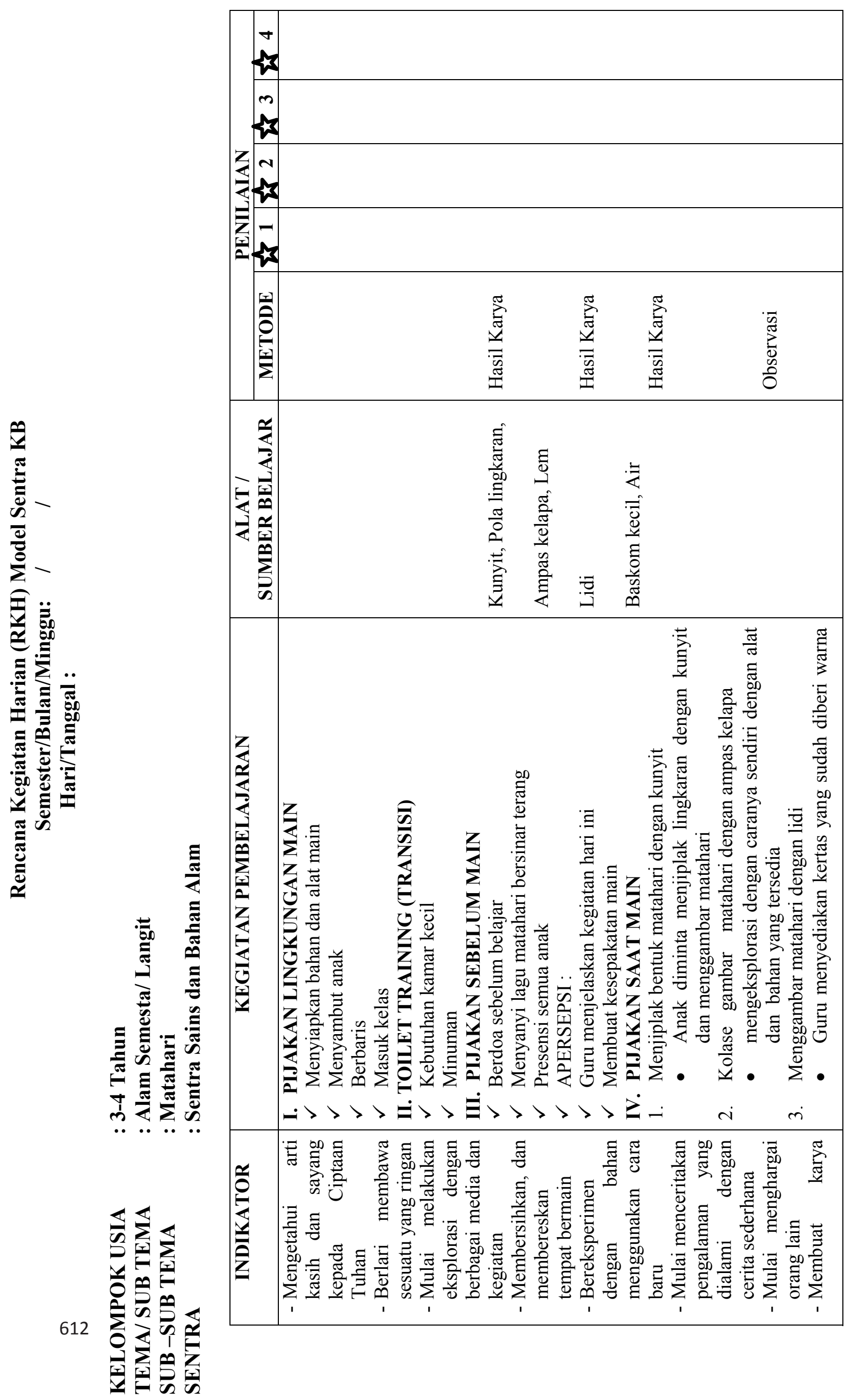
Jurnal Pendidikan Anak, Volume IV, Edisi 2, Desember 2015

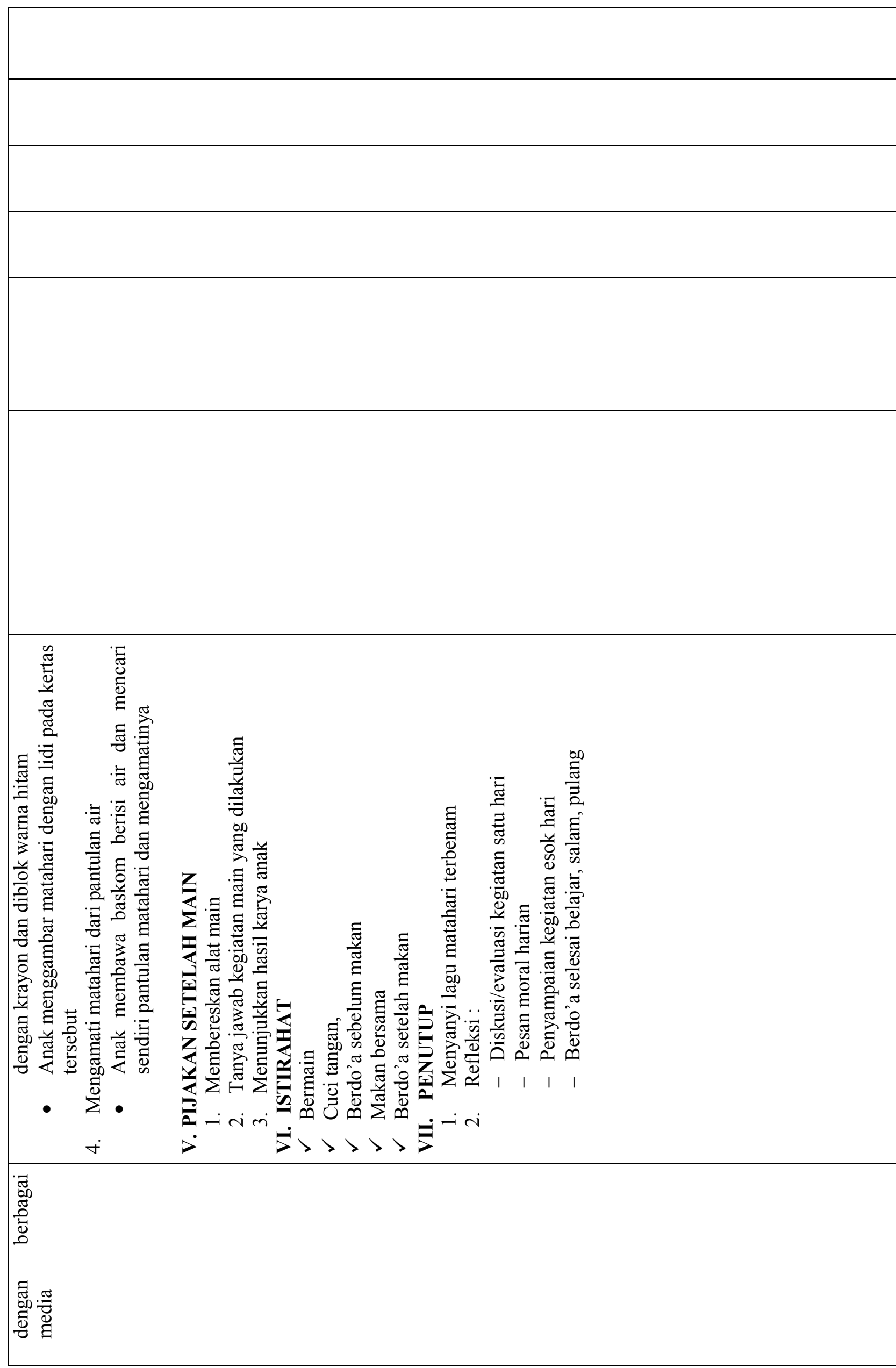


Jurnal Pendidikan Anak, Volume IV, Edisi 2, Desember 2015

을
$\frac{0}{E}$
을
$\frac{1}{5}$
$\frac{1}{5}$

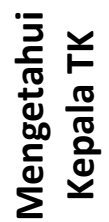




\section{KESIMPULAN}

Setelah diberikan pelatihan guru-guru di TK N Pratama mulai dapat membuat Rencana Kegiatan Harian. Setelah masuk tahun ajaran baru, selesai kegiatan pembelajaran guru tidak langsung pulang tetapi membuat perangkat pembelajaran dan medianya. Guru-guru pun lebih kreatif dan tidak hanya berpacu pada LKA.

\section{DAFTAR PUSTAKA}

Assolihin, 2013 dalam http://paudanakbermainbelaja r.blogspot.co.id/2013/05/peng ertian-konsep-dan-teoribcct.html

Azzahra Assyifa dalam http://www.paudbfqnaskdb.bl ogspot.co.id/2014/10/caramenyusun-satuan-kegiatan$\underline{\text { harian.html }}$ (Dirjen Manajemen Dikdas dan Menengah, Kemdiknas RI: 2010

Eka Mandasari dalam http://ejournal.unesa.ac.id/arti cle/4980/14/article.pdf

Harun Rasyid, Mansyur \& Suratno. (2009). Asesmen Perkembangan Siswa Usia Dini. Multi Presindo:

Yogyakarta 